\title{
The use of yeast-fermented cassava roots as a sole source of protein in beef cows
}

\author{
C. Promkot and P. Pornanek ${ }^{1}$ \\ Rajamangala University of Technology Isan, Faculty of Natural Resources, Department of Animal Science \\ SkonNakhon Campus, Post Box 47160, Thailand
}

KEY WORDS: beef cattle, cassava, root, yeast, Saccharomyces cerevisiae, protein

Received: 16 December 2019

Revised: $\quad 2$ June 2020

Accepted: 7 August 2020

${ }^{1}$ Corresponding author:

e-mail: ppitukpol@hotmail.co.th

\begin{abstract}
Four ruminally-cannulated non-pregnant Brahman beef cows (body weight $(\mathrm{BW})=430 \mathrm{~kg}$ ) were used to study the effects of yeast-fermented cassava roots (YEFECAR) as the sole source of protein on dry matter (DM) intake and nutrient digestibility. Animals were allotted to groups fed YEFECAR at levels: $0,20,30,35 \% \mathrm{DM}$, according to a $4 \times 4$ Latin square design. Cows were fed rice straws (as a roughage) ad libitum; concentrate treatments (1.5\% BW per day) were offered twice daily. It was indicated that the use of YEFECAR in a concentrate diet reduced feed intake $(P<0.05)$ but had no effects on nutrient digestibility, rumen ecology $\left(\mathrm{pH}, \mathrm{NH}_{3}-\mathrm{N}\right)$, rumen volatile fatty acid concentration, rumen bacterial population and microbial protein. Accordingly, it can be concluded that the use of YEFECAR as the primary source of protein at $20 \%$ DM or higher in concentrate feed can lower the feed intake, which may subsequently affect livestock yield. To ensure optimal utilization of YEFECAR as the main source of protein in ruminant feed further studies on increasing the sulphur content in yeast medium prior to the production of YEFECAR are needed.
\end{abstract}

\section{Introduction}

Farming ruminants in tropical conditions is often challenged by the shortage of roughage (both of its quantity and quality), and especially a lack of protein sources during the drought season (Wanapat and Devendra, 1992), resulting in reduced livestock yield (Leng, 1990). One of many ways to solve the shortage of good quality roughage during the dry season is feeding livestock a concentrate feed. However, such type of feed is expensive as it is produced from protein sources such as soybean meal (SBM) a locally rare animal feed ingredient that must be imported. In effect farmers do not supplement their livestock with concentrate feed or use only limited concentrate feed, which leads to a decreased livestock production. Finding a cheaper protein source that can be procured locally to replace SBM in concentrate feed will be a solution.

Cassava is considered as an important economic crop in tropical countries and it is extensively cultivated. Therefore, cassava as inexpensive protein source is widely used among livestock producers. Cassava can be fermented with yeast to produce yeast-fermented cassava products with a high level of protein and has the potential to be an alternative source of protein replacing SBM. This yeast-fermented cassava product is also cheaper than SBM (yeast-fermented cassava product costs approximately $1015 \mathrm{THB}$ per $\mathrm{kg}$, while soybean meal -1525 THB per kg; 1 USD $=31.78 \mathrm{THB}$ ). The use of yeast-fermented cassava products as a source of protein in ruminant feed has been widely studied (Boonnop et al., 2009, 2010; Wanapat et al., 2011; 
Promkot et al., 2013, 2017; Cherdthong and Supapong, 2019), owing to the fact that cassava plants thrive well in low-fertility soils, especially in the north-eastern region of Thailand and sub-Saharan African countries. Hence, these products are considered a good source of protein for ruminant animals (Boonnop et al., 2009). According to the study conducted by Boonnop et al. (2009), cassava chips (dried cassava roots) or fresh cassava roots can be fermented with yeast (Baker's yeast or Saccharomyces cerevisiae) to produce yeast-fermented cassava chips (YEFECAP) or yeast-fermented cassava roots (YEFECAR), resulting in an increase of protein content from 3\% dry matter (DM) in non-fermented products to $21-30 \% \mathrm{DM}$ in fermented ones. The use of YEFECAP in ruminant feed was further studied by Boonnop et al. (2010). Initially, the digestive trial was conducted on 4 rumen-fistulated Holstein-Friesian dairy crossbred steers. Animals were fed YEFECAP in concentrate diets at $0,33,67$ and $100 \%$ by replacing SBM (YEFECAP in concentrate diets at 0, 7, 17 and $28 \%$ DM, respectively). It was shown that YEFECAP can fully replace SBM by improving rumen fermentation efficiency and nutrient digestibility. Wanapat et al. (2011) conducted a digestion study with YEFECAP replacing SBM in concentrate diets and reported similar results as Boonnop et al. (2010). Specifically the results indicate that YEFECAP was able to fully replace SBM in concentrate diets for dairy cows and had positive effects on rumen fermentation, DM intake, nutrient digestibility, milk yield and composition. Similarly, Promkot et al. (2013) conducted a feeding trial on periparturient dairy cows by comparing the digestibility and production of dairy cows that were fed without (SBM as a protein source) and with YEFECAP (YEFECAP as a protein source) in concentrate diets. According to the results, the use of YEFECAP at $11.9 \%$ DM in concentrate diets for prepartum cows and up to $26 \%$ DM for lactating cows could enhance DM intake, crude protein $(\mathrm{CP})$ and neutral detergent fibre (NDF) digestibility. Based on previous studies, YEFECAP up to $28 \%$ DM can serve as a good protein source fully replacing SBM in concentrate diets. However, the use of YEFECAR (fresh roots) in ruminant feed has not been widely studied due to weather limitations as producing cassava chips is difficult during the rainy season. Since fresh cassava roots contain a high level of hydrogen cyanide (HCN) that is toxic to animals, YEFECAR could be a possible alternative due to its relatively high protein content and low toxicity. Recently, Promkot et al. (2017) conducted a digestibility trial on four Brahman beef cattle by replacing SBM with YEFECAR (prepared according to Boonnop et al. (2009) in concentrate diets at 0, 50, 80 and $100 \%$ replacement levels (YEFECAR in concentrate diets: $0,10,20$ and $30 \% \mathrm{DM}$, respectively)). It was suggested that the use of YEFECAR at 20\% DM in concentrate feed could improve rumen bacterial population and NDF digestibility. Moreover, no negative effects were found when the cattle were fed $30 \%$ DM of YEFECAR or $100 \%$ replacement of SBM in concentrate diets.

So, the aim of this study was to examine whether it is possible to feed ruminants with YEFECAR as the sole source of protein $(100 \%$ replacement of SBM), as well as to determine the appropriate level of YEFECAR in feed. Therefore, the objective of this study is to evaluate the effects of the use of YEFECAR as the sole source of protein on DM intake and nutrient digestibility in cattle.

\section{Material and methods}

\section{Animals, design and treatments}

Four ruminally cannulated non-pregnant Brahman beef cows (body weight $(\mathrm{BW})=430 \mathrm{~kg}$ ) were arranged according to a $4 \times 4$ Latin square design to study the effects of the level of YEFECAR in concentrate diets on DM intake and nutrient digestibility. The study was conducted in four periods, each lasted 21 days with the last 7 days of sampling collection. Animals were fed concentrate with different levels of YEFECAR: T1 diet (control) $0 \%$ DM of YEFECAR (SBM as a protein source, $100 \%$ ); T2 diet $20 \%$ DM of YEFECAR (SBM 0\%); T3 diet 25\% DM of YEFECAR (SBM $0 \%$ ), and T4 diet 30\% DM of YEFECAR (SBM 0\%).

\section{Yeast-fermented cassava root (YEFECAR) preparation}

Fresh cassava roots (better variety, Rayong 72) were cultivated in Phang Khon District, Sakon Nakhon Province, Thailand. The preparation of fermented yeast was carried out according to the method of Boonnop et al. (2009). Briefly, fresh cassava roots were chopped into small cubes of 2-4 cm and fermented in a closed container for three weeks before being fermented with the yeast medium. The preparation of yeast medium was as follows: activated yeasts were prepared using $1 \mathrm{~kg}$ of Baker's yeast (Saccharomyces cerevisiae) and $1 \mathrm{~kg}$ of sugar mixed with 51 of tap water. The mixture was incubated at room temperature for $1 \mathrm{~h}$. 
This solution was called 'Solution A'. The liquid medium was prepared using $1.2 \mathrm{~kg}$ of molasses and 51 of tap water, followed by the addition of $2.4 \mathrm{~kg}$ of urea (urea fertilizer N-P-K=46-0-0). The $\mathrm{pH}$ of the solution was adjusted using $\mathrm{H}_{2} \mathrm{SO}_{4}$ to achieve the final $\mathrm{pH}$ of 3.5-5. This solution was called 'Solution B'. Next, solutions A and B were mixed together at a 1:1 ratio and flushed with air at room temperature for 3 days by using an air pump $(600 \mathrm{~W})$. This mixed solution was called 'Yeast medium'. The yeast medium solution was mixed with fermented fresh cassava roots at a ratio of 11 to $2 \mathrm{~kg}$ DM. The mixture was then fermented in a closed container for $120 \mathrm{~h}$, resulting in the final product YEFECAR. YEFECAR was prepared on a weekly basis.

\section{Animal management, feed and feeding}

Two weeks prior to the experiment, cows were dewormed by subcutaneous injection of $200 \mu \mathrm{g}$ of ivermectin $/ \mathrm{kg}$ of body weight. Cows were then kept in an individual pens $(\mathrm{W} \times \mathrm{L}=3 \times 5 \mathrm{~m}$, concrete floor), containing water and mineral blocks (each $\mathrm{kg}$ of mineral block contains, g: $\mathrm{NaCl} 960, \mathrm{Ca} 3$, $\mathrm{Mg}$ 2.2, P 1.5, Fe 3.5, S 1, Ze 0.85; mg: Mn 0.22, I 50, K 15, Co 18, Se 10). The average daily minimum and maximum temperatures during the experimental period were 24 and $33^{\circ} \mathrm{C}$, respectively. The ingredients and chemical composition of concentrate treatments and roughages (rice straws) are shown in Table 1. Concentrate treatments were offered twice daily (7:00 and 16:00 at equal parts) at $1.5 \%$ BW per day. Roughages (rice straw) were given ad libitum.

\section{Data collection and sampling methods}

Body weight was recorded on days 14 and 21 of each period. Data for dry matter intake (DMI) calculation were obtained from the last 7 days of each period.

Rice straw and concentrate feed samples were collected daily during the last 7 days of each period and were stored at $-20{ }^{\circ} \mathrm{C}$ for further analysis. Faecal samples were collected twice a day (8:00 and 15:00) during the last two days of each period by means of rectal sampling. Composite faecal samples were immediately dried at $60^{\circ} \mathrm{C}$ for $48 \mathrm{~h}$ and stored at $-20^{\circ} \mathrm{C}$ until the analysis.

Rumen fluid samples were collected on day 21 of each period at 0 and $4 \mathrm{~h}$ post-feeding and were immediately measured for $\mathrm{pH}$ by using a portable pH meter (HI2002, edge ${ }^{\circledR}$, Hanna Instruments, Woonsocket RI, USA). The samples were then filtered through four layers of cheesecloth and centrifuged (3000 g, $4{ }^{\circ} \mathrm{C}$ for $\left.15 \mathrm{~min}\right)$. The supernatants were divided into two portions. The first 50-ml portion was stored in a plastic bottle to which $5 \mathrm{ml}$ of $1 \mathrm{M} \mathrm{H}_{2} \mathrm{SO}_{4}$ was added; the mixture was then stored at $-20^{\circ} \mathrm{C}$ for $\mathrm{NH}_{3}-\mathrm{N}$ analysis. The second $1-\mathrm{ml}$ portion was stored in a plastic bottle to which $9 \mathrm{ml}$ of $10 \%$ formalin solution was added. The mixture was stored at $4{ }^{\circ} \mathrm{C}$ to be used for total direct count of bacteria, protozoa and fungal zoospores.

Blood samples were obtained from jugular veins and stored in a serum separation tube at the time of rumen fluid sampling. The samples were centrifuged (3000 $\mathrm{g}, 4^{\circ} \mathrm{C}$ for $15 \mathrm{~min}$ ), and the supernatants were decanted and frozen $\left(-20^{\circ} \mathrm{C}\right)$ for analysis.

Table 1. Ingredients and chemical composition of concentrate treatments (different levels of yeast-fermented cassava roots (YEFECAR))

\begin{tabular}{|c|c|c|c|c|c|}
\hline \multirow{2}{*}{ Indices } & \multicolumn{4}{|c|}{ YEFECAR in concentrate feed (\% of dry matter (DM)) } & \multirow{2}{*}{ Rice straw } \\
\hline & 0 (Control) & 20 & 25 & 30 & \\
\hline \multicolumn{6}{|l|}{ Ingredients, \% DM } \\
\hline cassava chip & 78.6 & 64.8 & 59.9 & 55.1 & \\
\hline YEFECAR & 0.0 & 20.0 & 25.0 & 30.0 & \\
\hline rice bran & 5.8 & 6.2 & 6.2 & 6.2 & \\
\hline soybean meal & 6.7 & - & - & - & \\
\hline molasses & 4.0 & 4.0 & 4.0 & 4.0 & \\
\hline urea & 2.5 & 2.5 & 2.5 & 2.3 & \\
\hline salt & 1.1 & 1.1 & 1.1 & 1.1 & \\
\hline sulphur & 0.2 & 0.2 & 0.2 & 0.2 & \\
\hline mineral mix ${ }^{1}$ & 1.1 & 1.1 & 1.1 & 1.1 & \\
\hline \multicolumn{6}{|c|}{ Chemical composition, \% DM } \\
\hline $\mathrm{DM}, \%$ of fresh matter & 88.3 & 69.3 & 65.8 & 62.6 & 89.5 \\
\hline crude protein & 12.8 & 12.8 & 12.8 & 12.8 & 3.5 \\
\hline neutral detergent fibre & 9.3 & 9.1 & 9.1 & 9.1 & 74.3 \\
\hline acid detergent fibre & 5.0 & 4.7 & 4.6 & 4.6 & 48.1 \\
\hline $\mathrm{TDN}^{2}$ & 75.0 & 75.0 & 75.0 & 75.0 & 49.4 \\
\hline
\end{tabular}

${ }^{1}$ contained per $\mathrm{kg}: \mathrm{g}$ : iron 2.14 , iodine 0.15 , sulphur 11.82 , copper 0.23 , magnesium 0.96 , sodium 2.68 , manganese 7.21 , cobalt 0.03 , phosphorus 19.60, selenium 0.003, zinc 0.16 , calcium 204.03; ${ }^{2}$ TDN - calculated total digestible nutrients 
Urine samples were collected twice a day for a period of two days (morning and afternoon of the last two days of each period) by stimulating the perineum of the cow with a light rubbing motion. The samples were then stored in a plastic container that contained a suitable amount of $50 \% \mathrm{H}_{2} \mathrm{SO}_{4}$ to reduce the $\mathrm{pH}$ level to $<2.5$. Additional urine subsamples were immediately diluted and stored at $-20{ }^{\circ} \mathrm{C}$ for analysis.

\section{Laboratory analysis and calculation}

Composite faecal and feed samples were ground (1 mm screen) and analysed for DM, ash and crude protein (CP) contents (AOAC International, 2005), neutral detergent fibre (NDF) and acid detergent fibre (ADF) (Goering and Van Soest, 1970), and acid-insoluble ash (AIA; Van Keulen and Young, 1977). AIA was used to estimate the digestibility of nutrients (Van Keulen and Young, 1977). It was prepared by drying and ashing the sample, and boiling the ashed sample in $2 \mathrm{M}$ hydrochloric acid for five minutes. The ash content was determined gravimetrically after the hot hydrolysate had been filtered, washed free of acid, and re-ashed. The digestibility of nutrients was calculated as the ratio of AIA in feed and faeces.

The $\mathrm{NH}_{3}-\mathrm{N}$ and volatile fatty acids (VFA) concentrations in rumen fluids were analysed by micro-Kjeldahl (FOSS, Hillerød, Denmark) (AOAC International, 2005) and high-performance liquid chromatography (HPLC) (Mathew et al., 1997) methods, respectively. The total direct count of bacteria, protozoa and fungal zoospores in rumen fluids were carried out by employing the method of Galyean (1989) based on the use of a haemocytometer (Boeco, Hamburg, Germany). The bacterial and protozoal shapes of the specimen were analysed under a microscope. Rumen fungal zoospores and small protozoa were identified based on their ultrastructural characteristics; fungal zoospores have flagella while protozoa have ciliates. Rumen fluid was diluted with sterile water by 100,10 and 10 times for bacteria, protozoa and fungal zoospore counting using $10 \times 4,10 \times 10$ and $10 \times 40$ ocular $\times$ objective of haemocytometer, respectively.

Blood serum was analysed for blood urea nitrogen (BUN) by using BUN colorimetric detection kit.

Urine samples were analysed for purine derivatives (PD: uric acid and allantoin; IAEA,1997) and creatinine (by creatinine assay kit). The microbial protein synthesis was calculated based on purine derivatives:creatinine (PDC) index, PD excretion and PD absorption according the following equation:

$$
\mathrm{Y}=\mathrm{a} \chi
$$

where: $\mathrm{Y}$ - PDC index (kg), a - PD to creatinine ratio, $\chi$ - metabolic body weight $(\mathrm{kg})$. PD and creatinine concentrations are expressed in $\mathrm{mmol} / \mathrm{l}$ (Cetinkaya et al., 2006).

Since the daily PD excretion and PDC index are linearly correlated, the former can be estimated by using the following equation:

$$
\mathrm{Y}=\mathrm{a}+\mathrm{Cx}
$$

where: Y - PD excretion (mmol/day), a - PD to creatinine ratio, $\mathrm{x}-\mathrm{PDC}$ index (purine derivatives:creatinine), C - regression coefficient, which corresponds to the average daily creatinine excretion expressed in $\mathrm{kg} / \mathrm{kg} \mathrm{W} \mathrm{W}^{0.75}$, where $\mathrm{W}^{0.75}$ - the metabolic body weight $(\mathrm{kg})$ of the animal (Cetinkaya et al., 2006).

Purine derivative absorption (X) can be calculated using the following equation:

$$
\mathrm{Y}=0.85 \mathrm{X}+\left(0.385 \mathrm{~W}^{0.75}\right)
$$

where: $\mathrm{Y}$ - PD excretion (mmol/day), $\mathrm{X}$ - purine derivative absorption (once $\mathrm{Y}$ is determined, $\mathrm{X}$ can be calculated), $\mathrm{W}^{0.75}$ - the metabolic body weight $(\mathrm{kg})$ of the animal.

The microbial $\mathrm{N}$ yield was calculated using:

$$
\text { Microbial N }(\mathrm{gN} / \mathrm{d})=\frac{\mathrm{X}(\mathrm{mmol} / \mathrm{d}) \times 70}{0.116 \times 0.83 \times 1000}
$$

\section{Statistical analysis}

Statistical analysis was performed by using the general linear model of SAS Institute Inc. (SAS, 2009). The mean differences with a significant $F$-value $(P<0.05)$ were statistically compared using Duncan's new multiple-range test.

\section{Results and discussion}

Dry matter intake and nutrient digestibility. The use of YEFECAR (at $0-30 \%$ DM) as the main source of protein for beef cows resulted in a lower level of DMI $(P<0.05)$, specifically in the case of concentrate feed (Table 2). The foregoing observation is in line with the results of the study by Promkot et al. (2017), in which it was found that the use of YEFECAR at 30\% DM in concentrate feed (100\% replacement of SBM) could lead to a lower feed intake. Based on the results of this experiment and previous studies it can be suggested that the use of YEFECAR as the primary source of protein in concentrate feed has a tendency to cause lower levels of DM intake. This may be connected with the chemical composition of YEFECAR, which contains approximately $47.3 \mathrm{mg} / \mathrm{kg}$ of $\mathrm{HCN}$ (Boonnop et al., 2009) that contributes to loss of appetite in animals 
Table 2. Effects of the level of yeast-fermented cassava roots (YEFECAR) in concentrate diet on dry matter intake and nutrient digestion coefficients in beef cattle

\begin{tabular}{|c|c|c|c|c|c|c|}
\hline \multirow{2}{*}{ Indices } & \multicolumn{4}{|c|}{ YEFECAR in concentrate feed (\% of dry matter (DM)) } & \multirow{2}{*}{ SEM } & \multirow{2}{*}{$P$-value } \\
\hline & 0 (Control) & 20 & 25 & 30 & & \\
\hline \multicolumn{7}{|l|}{ DM intake, kg/head/day } \\
\hline concentrate & $6.3^{\mathrm{a}}$ & $5.3^{b}$ & $5.2^{b}$ & $5.0^{\mathrm{b}}$ & 0.20 & 0.043 \\
\hline rice straw & 3.5 & 2.5 & 3.3 & 3.2 & 0.30 & 0.219 \\
\hline total & 9.8 & 7.8 & 8.5 & 8.4 & 0.60 & 0.244 \\
\hline \multicolumn{7}{|l|}{$\%$ of body weight } \\
\hline concentrate & $1.4^{\mathrm{a}}$ & $1.2^{b}$ & $1.2^{b}$ & $1.1^{b}$ & 0.2 & 0.036 \\
\hline rice straw & 0.8 & 0.6 & 0.7 & 0.7 & 0.4 & 0.101 \\
\hline total & $2.2^{\mathrm{a}}$ & $1.8^{\mathrm{b}}$ & $1.9^{b}$ & $1.8^{\mathrm{b}}$ & 0.5 & 0.045 \\
\hline \multicolumn{7}{|c|}{ Apparent total tract digestibility, \% DM } \\
\hline DM & 69.1 & 75.6 & 74.5 & 68.6 & 2.7 & 0.261 \\
\hline crude protein & 73.1 & 78.4 & 74.2 & 74.7 & 4.0 & 0.807 \\
\hline neutral-detergent fibre & 47.5 & 48.8 & 49.2 & 48.6 & 3.3 & 0.980 \\
\hline acid-detergent fibre & 42.2 & 43.2 & 44.5 & 44.7 & 2.6 & 0.188 \\
\hline
\end{tabular}

ab - means with different superscripts in the same row are significantly different at $P<0.05$ (according to Duncan's new multiple-range test); SEM - standard error of the mean

(Paulinus and Obaika, 2013). In addition, the presence of $\mathrm{HCN}$ in ruminant feed leads to higher levels of sulphur intake or sulphur-containing amino acids such as methionine and cysteine, for HCN detoxification (Promkot et al., 2007; Promkot and Wanapat, 2009; Cherdthong et al., 2018). According to the theory, $1.2 \mathrm{~g}$ of sulphur is required to detoxify $1 \mathrm{~g}$ of $\mathrm{HCN}$ (Wheeler et al., 1975). Hence, if the level of sulphur intake is insufficient for $\mathrm{HCN}$ detoxification, the level of feed intake will decrease. Ultimately, this implies that a high level of YEFECAR in feed may cause the level of sulphur to be inadequate for the nutrient needs and $\mathrm{HCN}$ detoxification of the ruminants. According to the study conducted by Promkot and Wanapat (2009), the level of feed intake in dairy cattle had a tendency to increase when sulphur content in concentrate feed was increased from 0.2 to $0.4 \%$ DM. Since only $0.2 \%$ of DM of sulphur was used in this study, there may be a lack of sulphur content in concentrate feed. Nonetheless, Promkot et al. (2017) found that the use of YEFECAR at 10-20\% in concentrate feed had no adverse effect on feed intake, although only $0.2 \%$ DM of sulphur was added to the concentrate feed. Such difference in the experimental results may be attributable to the presence of methionine and cysteine in SBM. Concerning the fact that in this experiment YEFECAR was used as the primary source of protein, the contents of methionine and cysteine may be relatively low. Although there has been no report on methionine and cysteine contents in YEFECAR, in the study conducted by Nagib and Sousa (2007) it was shown that cassava roots contain only $0-0.41 \mathrm{~g} / \mathrm{kg}$ DM of methionine and $0.25-0.26 \mathrm{~g} / \mathrm{kg} \mathrm{DM}$ of cysteine. Similarly, Watson (1976) found that the yeast Saccharomyces cerevisiae, which is cultivated from ammonium $\left(\mathrm{NH}_{4}^{+}\right)$used in protein synthesis, contains only $1.07 \mathrm{~g} / \mathrm{kg} \mathrm{DM}$ of methionine and less than $0.3 \mathrm{~g} / \mathrm{kg}$ DM of cysteine. Likewise, Wanapat and Kang (2015) reported only 0.16 and $0.05 \mathrm{~g} / \mathrm{kg}$ DM of methionine and cysteine in YEFECAP, respectively. Hence, it can be inferred that YEFECAR contains relatively low levels of methionine and cysteine, as well as lower levels of sulphur-containing amino acids than SBM. According to the report of Cavins et al. (1972), SBM contains relatively high levels of methionine and cysteine in comparison with cassava roots, specifically at 5.1 and $4.4 \mathrm{~g} / \mathrm{kg} \mathrm{DM}$, respectively. These findings suggest that a $100 \%$ replacement of SBM with YEFECAR in concentrate feed at the level above $20 \%$ DM will cause an increased demand for sulphur in ruminants. For future research, the amount of methionine and cysteine should be increased by adding sulphur to the yeast medium prior to yeast fermentation of cassava roots.

Regarding the effects of YEFECAR on nutrient digestibility, it was found that there were no adverse effects on the digestibility of DM and protein, which is in line with the study of Promkot et al. (2017). Nonetheless, Promkot et al. (2017) suggested that the use of YEFECAR at the level of $20 \% \mathrm{DM}$ in concentrate feed had a tendency to improve the digestibility of NDF and ADF due to the increase in rumen bacterial population. However, in this study it was found that the use of YEFECAR as the main source of protein in concentrate feed had no impact on the digestibility of NDF and ADF in beef cows, owing to the fact that there was no increase in rumen bacterial population (Table 3). 
Table 3. Effects of the level of yeast-fermented cassava roots (YEFECAR) in concentrate diet on rumen ecology, volatile fatty acid (VFA) concentration, rumen microorganisms and microbial $\mathrm{N}$ yield in beef cattle

\begin{tabular}{|c|c|c|c|c|c|c|}
\hline \multirow{2}{*}{ Indices } & \multicolumn{4}{|c|}{ YEFECAR in concentrate feed ( $\%$ of dry matter (DM)) } & \multirow{2}{*}{ SEM } & \multirow{2}{*}{$P$-value } \\
\hline & 0 (Control) & 20 & 25 & 30 & & \\
\hline \multicolumn{7}{|l|}{ Rumen pH } \\
\hline $\mathrm{H}=0$ & 6.62 & 6.58 & 6.88 & 7.05 & 0.35 & 0.760 \\
\hline $\mathrm{H}=4$ & 6.57 & 6.50 & 6.58 & 6.37 & 0.25 & 0.950 \\
\hline mean & 6.59 & 6.54 & 6.73 & 6.71 & 0.30 & 0.855 \\
\hline \multicolumn{7}{|c|}{ Rumen ammonia nitrogen $\left(\mathrm{NH}_{3}-\mathrm{N}\right), \mathrm{mg} / \mathrm{dl}$} \\
\hline $\mathrm{H}=0$ & 11.55 & 9.80 & 10.55 & 9.23 & 1.91 & 0.830 \\
\hline $\mathrm{H}=4$ & 11.60 & 11.08 & 13.58 & 11.90 & 1.69 & 0.750 \\
\hline mean & 11.57 & 10.44 & 12.06 & 10.56 & 1.80 & 0.791 \\
\hline Total VFA, mM & 75.6 & 72.7 & 72.4 & 73.2 & 6.0 & 0.724 \\
\hline \multicolumn{7}{|l|}{ VFA, mol/100 mol } \\
\hline acetate (C2) & 65.8 & 63.5 & 64.4 & 64.0 & 6.8 & 0.629 \\
\hline propionate (C3) & 24.0 & 24.0 & 26.4 & 26.8 & 2.2 & 0.533 \\
\hline butyrate (C4) & 10.2 & 12.5 & 10.2 & 10.2 & 1.4 & 0.543 \\
\hline $\mathrm{C} 2: \mathrm{C} 3$ & 2.7 & 2.6 & 2.4 & 2.3 & 0.3 & 0.964 \\
\hline \multicolumn{7}{|l|}{ Total direct counts } \\
\hline bacteria, $\times 10^{11} \mathrm{cell} / \mathrm{ml}$ & 1.2 & 1.0 & 1.1 & 1.1 & 0.4 & 0.425 \\
\hline protozoa, $\times 10^{6} \mathrm{cell} / \mathrm{ml}$ & 0.5 & 0.6 & 0.5 & 0.5 & 0.3 & 0.743 \\
\hline fungal zoospores, $\times 10^{6} \mathrm{cell} / \mathrm{ml}$ & 0.4 & 0.5 & 0.4 & 0.5 & 0.2 & 0.423 \\
\hline mMicrobial $\mathrm{N}$ yield, $\mathrm{g} \mathrm{N} /$ day & 74.4 & 73.8 & 73.9 & 73.7 & 4.0 & 0.639 \\
\hline
\end{tabular}

SEM - standard error of the mean

Another factor affecting the digestibility of nutrients is the rate of passage through the rumen of both particulate and liquid parts of the feed. If the rate of passage is rapid, the feed will not stay in the rumen for a long time, resulting in shorter time for microbial fermentation and reduced digestibility of total nutrients (Colucci et al., 1982). Therefore, the factors that affect the rate of passage of feed through the rumen should relatively affect the digestibility of overall nutrients. There are many factors that affect the rate of passage, such as the quality of roughage (Nsahlai and Apaloo, 2007), ratio of concentrate feed to roughage (Baumont et al., 2000), environmental temperature (Varga and Prigge, 1982) and physiological state (Gunter et al., 1990). In this research, animals were fed with the same type of roughage at a similar ratio to concentrate feed. They were kept in the same environment and were also animals of similar physiological characteristics. Therefore, although the information on the rate of passage of feed through the rumen was not collected in this study, it could be expected that the rate of passage of the animals from control and experimental groups were similar. Another factor that could be used to indicate no difference in the rate of passage of feed through the rumen between animals in control and experimental groups was the similar amount of microbial $\mathrm{N}$ yield (Table 3 ) as the rate of passage of feed through the rumen was found to be relevant to the microbial $\mathrm{N}$ yield. According to Pathak (2008) the efficiency of protein synthesis can increase by $20 \%$ if the rate of passage of feed through the rumen increases from 0.02 to 0.08 per h. However, in previous studies the influence of the rate of passage of feed through the rumen on the amount of feed intake was discussed. It was found that the increased rate of passage of feed through the rumen was found to also increase feed intake in ruminants (Lindberg et al., 1988; Seo et al., 2006). In this research, the intake of nutrients in the control group was found to be higher than in the YEFRCAR group, which might be due to the appetite for feed or other aforementioned factors rather than caused by the influence of the rate of passage of feed through the rumen. The increase in feed intake without the increased rate of passage could be explained by the augmented rumen capacity (Hummel et al., 2008). When considering NDF intake and rumen capacity in animals from control and experimental groups, it was found that NDF intake was lower than the highest NDF intake (1.2\% BW). Therefore, it could be deduced that their rumen did not reach its full capacity.

Rumen ecology. The use of YEFECAR as the primary source of protein in concentrate feed for beef cows had no effect on rumen ecology, both in the aspect of $\mathrm{pH}$ and $\mathrm{NH}_{3}-\mathrm{N}$ (Table 3). This result is consistent with the study of Promkot et al. (2017) in 
which YEFECAR had no impact on rumen $\mathrm{pH}$ and $\mathrm{NH}_{3}-\mathrm{N}$. However, the level of rumen $\mathrm{pH}(6.5-6.7)$ observed in this study was lower than 6.8-7 found by Promkot et al. (2017). Such difference in the $\mathrm{pH}$ levels may be explained by different methods of rumen fluid collection. More specifically, the fluid samples in this study were collected through rumen fistulas, which is a more precise method of determining rumen $\mathrm{pH}$ than the use of an oral stomach tube employed in the study of Promkot et al. (2017). According to the study of Enemark et al. (2002), rumen fluids collected by an oral stomach tube reflected a higher level of $\mathrm{pH}$ by approximately $0.39-1.31$ due to saliva contamination.

The concentration of rumen $\mathrm{NH}_{3}-\mathrm{N}$ depends on the level of protein and rumen degradable protein (RDP) in the feed (Promkot and Wanapat, 2005; Mutsvangwa et al., 2016). Since all beef cows in the experiment were given an equal amount of protein, there were no differences in the concentration of rumen $\mathrm{NH}_{3}-\mathrm{N}$. Moreover, the $\mathrm{NH}_{3}-\mathrm{N}$ concentration in the experiment was suitable for microbial growth. According to the report of Broderick (2005), the concentration of rumen $\mathrm{NH}_{3}-\mathrm{N}$ should be higher than $5 \mathrm{mg} / \mathrm{dl}$ for optimal rumen fermentation and synthesis of microbial protein. Regarding this experiment, the concentration of rumen $\mathrm{NH}_{3}-\mathrm{N}$ was $10.4-12.0 \mathrm{mg} / \mathrm{dl}$ which is higher than the recommended level.

Ruminal VFAs and microorganisms. According to Table 3, the level of YEFECAR in concentrate feed had no effects on the concentration of VFA, rumen bacterial population and amount of microbial protein. There has been no report on the effects of YEFECAR in concentrate diets on the concentration of ruminal VFA in beef cows yet. Nevertheless, in the study conducted by Polyorach et al. (2014) on the effects of yeast-fermented cassava chip protein (YEFECAP) on VFA concentration it was found that YEFECAP contributed to an increase in the concentration of total VFA and propionate due to the increase in rumen microbial population. Since YEFECAR was used in this experiment, there was no increase in the population of microorganisms, specifically bacteria. Thus, there was no change in the concentration of ruminal VFA. This result is inconsistent with the findings of the study of Promkot et al. (2017) in which YEFECAR and SBM as a source of protein in concentrate feed had a tendency to increase rumen bacterial population and microbial $\mathrm{N}$ yield. Such inconsistency could be attributable to the fact that this experiment used YEFECAR as the primary source of protein, which caused an increased demand for amino acids, particularly sulphur-containing amino acids, to detoxify cyanide in the YEFECAR. As previously mentioned, the amount of amino acids in the YEFECAR may be limited, hence impeding microbial growth and population in the rumen.

\section{Conclusions}

Based on the results of this study, it can be concluded that a $100 \%$ replacement of soybean meal (SBM) with yeast-fermented cassava roots (YEFECAR) at the level of $20 \%$ dry matter (DM) or higher contributes to a decrease in the level of DM intake but has no effects on nutrient digestibility, rumen ecology, microbial population and microbial protein. Concerning the fact that a decreased level of feed intake may adversely affect the yield and growth of ruminants, the use of YEFECAR as the main source of protein in concentrate feed for beef cows should be lower than $20 \%$ DM. Likewise, other sources of protein that comprise sulphur-containing amino acids should be incorporated into the feed. Additionally, further studies concerning the effects of the use of YEFECAR in conjunction with sulphur supplementation on livestock yield, or the increase of methionine and cysteine content in YEFECAR by adding sulphur to the yeast medium prior to the fermentation of cassava roots are needed. The use of YEFECAR in ruminants feeding at the level lower than $20 \%$ DM in concentrates feed should also be explored relatively with the feed intake and livestock yield.

\section{Acknowledgements}

We would like to express our sincere gratitude and appreciation to the Faculty of Natural Resources, Rajamangala University of Technology Isan, Sakon Nakhon Campus, Thailand, for providing laboratory animals and research facilities. We are also immensely grateful to the National Research Council of Thailand (NRCT) and Rajamangala University of Technology Isan for their financial support.

\section{References}

AOAC International, 2005. Official Methods of Analysis of AOAC International. 18 $8^{\text {th }}$ Edition. Gaithersburg, MD (USA)

Baumont R., Prache S., Meuret M., Morand-Fehr P., 2000. How forage characteristics influence behaviour and intake in small ruminants: A review. Livest. Prod. Sci. 64, 15-28, https://doi. org/10.1016/S0301-6226(00)00172-X 
Boonnop K., Wanapat M., Nontaso N., Wanapat S., 2009. Enriching nutritive value of cassava root by yeast fermentation. Sci. Agric. 66, 629-633, https://doi.org/10.1590/S010390162009000500007

Boonnop K., Wanapat M., Navanukraw C., 2010. Replacement of soybean meal by yeast fermented-cassava chip protein (YEFECAP) in concentrate diets fed on rumen fermentation, microbial population and nutrient digestibilities in ruminants. J. Anim Vet. Adv. 9, 1727-1734, https://doi.org/10.3923/ javaa.2010.1727.1734

Broderick G.A., 2005. Factors affecting microbial protein synthesis in the Rumen with emphasis on diets based on Tropical forages. In: P. Rowlinson, C. Wachirapakorn, P. Pakdee, M. Wanapat (Editors). Integrating Livestock-crop Systems to Meet the Challenges of Globalisation. Proceedings of the AHAT/BSAS International Conference, November 14-18, Khon Kaen (Thailand), Vol. 1, pp. 249-259

Cavins J.F., Kwolek Y.F., Inglett G.E., Cowan J.C., 1972. Amino acid analysis of soybean meal: interlaboratory study. J. AOAC 55, 686-691, https://doi.org/10.1093/jaoac/55.4.686

Cetinkaya N., Yaman S., Baber N.H.O., 2006. The use of purine derivatives/creatinine ratio in spot urine samples as an index of microbial protein supply in Yerli Kara crossbred cattle. Livest. Sci. 100, 91-98, https://doi.org/10.1016/j. livprodsci.2005.07.004

Cherdthong A., Khonkhaeng B., Seankamsorn A., Supapong C., Wanapat M., Gunun N., Gunun P., Chanjula P., Polyorach S., 2018. Effects of feeding fresh cassava root with high-sulfur feed block on feed utilization, rumen fermentation, and blood metabolites in Thai native cattle. Trop. Anim. Health Prod. 50, 1365-1371, https://doi.org/10.1007/s11250-018-1569-8

Cherdthong A., Supapong C., 2019. Improving the nutritive value of cassava bioethanol waste using fermented yeast as a partia replacement of protein source in dairy calf ration. Trop. Anim. Health Prod. 51, 2139-2144, https://doi.org/10.1007/s11250019-01911-4

Colucci P.E., Chase L.E., Van Soest P.J., 1982. Feed intake, apparent diet digestibility, and rate of particulate passage in dairy cattle. J. Dairy Sci. 65, 1445-1456, https://doi.org/10.3168/ jds.S0022-0302(82)82367-9

Enemark J.M.D., Jorgensen R.J., Enemark P.S., 2002. Rumen acidosis with special emphasis on diagnosis aspects of subclinical rumen acidosis: a review. Vet. Zootech-Lith. 42, 16-29

Galyean M., 1989. Laboratory Procedure In Animal Nutrition Research. $1^{\text {st }}$ Edition. Department of Animal and Life Science, New Mexico States University. Las Cruces (Mexico)

Goering H.K., Van Soest P.J., 1970. Forage fiber analysis (apparatus, reagent, procedures and some application). In: Agriculture Handbook no. 379. ARS-USDA, Washington, DC (USA)

Gunter S., Judkins M., Krysl L., Broesder J., Barton R., Rueda B.R., Hallford D.M., Holcombe D.W., 1990. Digesta kinetics, ruminal fermentation characteristics and serum metabolites of pregnant and lactating ewes fed chopped alfalfa hay. J. Anim. Sci. 68, 3821-3831, https://doi.org/10.2527/1990.68113821x

Hummel J., Steuer P., Sudekum K.H., Hammer S., Hammer C., Streich W.J., Clauss M., 2008. Fluid and particle retention in the digestive tract of the addax antelope-adaptations of a grazing desert ruminant. Comp. Biochem. Physiol. Part A Mol. Integr. Physiol. 149, 142-149, https://doi.org/10.1016/j. cbpa.2007.11.001

IAEA (International Atomic Energy Agency), 1997. Estimation of rumen microbial protein production from purine derivatives in urine. A laboratory manual for FAO/IAEA Co-ordinated Research Programme. IAEA-TECDOC-945, IAEA, Vienna (Austria)
Leng R.A., 1990. Factors affecting the utilization of poor-quality forages by ruminants particularly under tropical conditions. Nutr. Res. Rev. 3, 277-303, https://doi.org/10.1079/NRR19900016

Lindberg J.E., 1988. Retention times of small feed particles and of water in the gut of dairy goats fed at different levels of intake. J. Anim. Physiol. An. N. 59, 173-181, https://doi. org/10.1111/j.1439-0396.1988.tb00062.x

Mathew S., Sagathewan S., Thomas J., Mathen G., 1997. An HPLC method for estimation of volatile fatty acids of ruminal fluid. Indian J. Anim. Sci. 67, 805-807

Mutsvangwa T., Davies K.L., McKinnon J.J., Christensen D.A., 2016. Effects of dietary crude protein and rumen-degradable protein concentrations on urea recycling, nitrogen balance, omasal nutrient flow, and milk production in dairy cows. J. Dairy Sci. 99, 6298-6310, https://doi.org/10.3168/jds.2016-10917

Nagib M.A.N., Sousa M.V., 2007. Amino acid profile in cassava and its interspecific hybrid. Genet. Mol. Res. 6, 292-297

Nsahlai I.V., Apaloo J., 2007. On the suitability of the Illius and Gordon's model for simulating the intake and digestibility of roughage diets by ruminants. S. Afr. J. Anim. Sci. 37, 275-289, https:// doi.org/10.4314/sajas.v37i4.4101

Pathak A.K., 2008. Various factors affecting microbial protein synthesis in the rumen. Vet. Worldl. 1, 186-189

Paulinus O.N., Obaika U.S., 2013. A comparative study of the toxic effects of prolonged intake of cassava-borne organic cyanide and inorganic cyanide in some rabbit tissues. J. Pharm. Sci. Innov. 2, 65-69, https://doi.org/10.7897/2277-4572.02457

Polyorach S., Wanapat M., Cherdthong A., 2014. Influence of yeast fermented cassava chip protein (YEFECAP) and roughage to concentrate ratio on ruminal fermentation and microorganisms using in vitro gas production technique. Asian-Australas J. Anim. Sci. 27, 36-45, https://doi.org/10.5713/ajas.2013.13298

Promkot C., Nitipot P., Piamphon N., Abdullah N., Promkot A., 2017. Cassava root fermented with yeast improved feed digestibility in Brahman beef cattle. Anim. Prod. Sci. 57, 1613-1617, https://doi.org/10.1071/AN15685

Promkot C., Wanapat M., 2005. Effect of level of cottonseed meal and protein in diets containing cassava chips and rice straw for lactating dairy cows. Asian-Australas. J. Anim. Sci. 18, 502-511, https://doi.org/10.5713/ajas.2005.502

Promkot C., Wanapat M., 2009. Effect of elemental sulfur supplementation on rumen environment parameters and utilization efficiency of fresh cassava foliage and cassava hay in dairy cattle. Asian-Australas. J. Anim. Sci. 22, 1366-1376, https://doi.org/10.5713/ajas.2009.90141

Promkot C., Wanapat M., Mansathit J., 2013. Effects of yeast fermented cassava chip protein (YEFECAP) on dietary intake and milk production of Holstein crossbred heifers and cows during pre- and post-partum period. Livest. Sci. 154, 112-116, https://doi.org/10.1016/j.livsci.2013.02.022

Promkot C., Wanapat M., Wachirapakorn C., Navanukraw C., 2007. Influence of sulfur on fresh cassava foliage and cassava hay incubated in rumen fluid of beef cattle. Asian-Australas. J. Anim. Sci. 20, 1424-1432, https://doi.org/10.5713/ ajas.2007.1424

Seo S., Tedeschi L.O., Schwab C.G., Garthwaite B.D., Fox D.G., 2006. Evaluation of the passage rate equations in the dairy NRC (2001) model. J. Dairy Sci. 89, 2327-2342, https://doi. org/10.3168/jds.S0022-0302(06)72304-9

SAS (Statistical Analysis System), 2009. SAS/STAT User's Guide: Statistics, Version 9.2. 2nd Edition. SAS Institute Inc., Cary, NC (USA) 
Wanapat M., Devendra C., 1992. Feeding and nutrition of dairy cattle and buffaloes in Asia. Sustainable Animal Production. In Proceedings $6^{\text {th }}$ AAAP Animal Science Congress. Bangkok (Thailand), pp. 177-194

Wanapat M., Boonnop K., Promkot C., Cherdthong A., 2011. Effects of alternative protein sources on rumen microbes and productivity of dairy cows. Maejo Int. J. Sci. Technol. 5, 13-23

Wanapat M., Kang S., 2015. Cassava chip (Manihot esculenta Crantz) as an energy source for ruminant feeding. Anim. Nutr. 1, 266-270, https://doi.org/10.1016/j.aninu.2015.12.001

Watson T.G., 1976. Amino-acid pool composition of Saccharomyces cerevisiae as a function of growth rate and amino-acid nitrogen source. J. Gen. Microbiol. 96, 263-268, https://doi. org/10.1099/00221287-96-2-263
Wheeler J.L., Hedges D.A., Till A.R., 1975. A possible effect of cyanogenic glucoside in sorghum on animal requirements for sulfur. J. Agric. Sci. 84, 377-379, https://doi.org/10.1017/ S0021859600052539

Van Keulen J., Young B.A., 1977. Evaluation of acid insoluble ash as a neutral marker in ruminant digestibility studies. J. Anim. Sci. 44, 282-287, https://doi.org/10.2527/jas1977.442282x

Varga G.A., Prigge E., 1982. Influence of forage species and level of intake on ruminal turnover rates. J. Anim. Sci. 55, 1498-1504, https://doi.org/10.2527/jas1982.5561498x 